\title{
日本発顧みられない熱帯病治療薬開発への挑戦
}

\author{
北 潔, $a, \uparrow$ 山田陽 城, ${ }^{*}, b, c$
}

\section{The Challenge of Developing New Treatments for NTDs Originating from Japan}

\author{
Kiyoshi Kita ${ }^{a, \dagger}$ and Haruki Yamada ${ }^{*, b, c}$ \\ ${ }^{a}$ Graduate School of Medicine and Faculty of Medicine, The University of Tokyo; 7-3-1 Hongo, Bunkyo-ku, \\ Tokyo 113-0033, Japan: ${ }^{b}$ School of Pharmacy, Tokyo University of Pharmacy and Life Sciences; \\ 1432-1 Horinouchi, Hachioji, Tokyo 192-0392, Japan: and 'NPO DNDi Japan; 8-14-24 \\ Nishi-Shinjuku KF Bldg. 704, Nishi-Shinjuku, Shinjuku-ku, Tokyo 160-0023, Japan.
}

2013 年 12 月にギニア南部で始まったエボラ出血 熱は，2014 年の集団発生事例が報告されて以降西 アフリカでその感染が拡大し, 一日で 150 名以上の 死者が増える状況が続いた．現在は減少しつつある が死者は 2015 年 5 月 20 日現在 11135 名を超えてい る. そして日本においても 70 年間発生のなかつた デング熱の患者が 2014 年夏に報告され，引きつづ き注意が喚起されている. その後も 2015 年春には MERS が韓国で発生する等, 感染症の発生が絶え 間ない. 昨今の地球規模での自由なヒトの往来や, 地球温暖化, 人獣共通感染症, 感染を媒介する蚊等 の発生は，国外で発生した感染症についても迅速な 診断と多角的な防疫体制の確立, 予防・治療薬の迅 速な開発が極めて重要であることを示している．途 上国の熱帯地域の貧困層を中心に蔓延するアフリカ 睡眠病, リーシュマニア症, シャーガス病, デング 熱を始めとする 17 の感染症は, World Health Organization（WHO，世界保健機関）により「顧み られない熱帯病」（ neglected tropical diseases; NTDs）と定義され，世界 149 力国の 14 億人が感

\footnotetext{
${ }^{a}$ 東京大学大学院医学系研究科（T113-0033 東京都文 京区本郷 7-3-1), $b$ 東京薬科大学薬学部 ( $\overline{1} 192-0392$ 東京都八王子市堀之内 $1432-1$ ), $c$ 特定非営利活動法人 DND $i$ Japan（₹160-0023 東京都新宿区西新宿 8-1424 西新宿 $\mathrm{KF}$ ビル 704)

現所属: ‘東京大学大学院医学系研究科 ( 東京都文京区本郷 7-3-1), 長崎大学大学院熱帯医学 グローバルヘルス研究科（干852-8523 長崎市坂本 112-4)

*e-mail: yamadaha@toyaku.ac.jp

日本薬学会第 135 年会シンポジウム S03 序文
}

染し, 年間 100 万人が死亡している. ${ }^{1,2}$ 最近の NTDs についてのWHO（世界保健機関）の報告書 でも，その感染地域が世界各地に拡大していること を警告し，各国に対しその対策を呼び掛けてい る. ${ }^{3)}$ NTDs に感染した患者の多くは貧困層の国々 に住む忘れられた人々であることから，その治療薬 は医薬品としての市場性がない。 そのため, NTDs の治療薬の開発や各国の取り組みは限られていた. これまでにNTDs 治療薬としては大村らによるオ ンコセルカ症やフィラリア症の治療薬であるイベル メクチンの発見による日本からの貢献が特記される が, 4) わが国全体が有するトップレベルの優れた創 薬力に比較して, NTDs 治療薬開発への成果は限ら れていた. しかしながら最近のエボラ出血熱感染の 例に見るように，グローバル化は地域を越え人類共 通の新たな劦威を生み出すことも懸念されるため, 産官学の連携による新たな仕組みの治療薬開発への 取り組みが急務である。今日, 途上国の感染症の新 規治療薬の研究開発・供給は官民連携の非営利組織 である医薬品開発パートナーシップ (Product Development Partnerships; PDPs)が産官学と連携し, リード化合物発見に至る開発の初期段階からフィー ルドにおける臨床試験までの一連の創薬研究を推進 し, 製品開発や流通支援を行う革新的開発メカニズ ムを創出し成果を上げている. ${ }^{5)}$ 本シンポジウムで は世界 NTDs 創薬のための国際パートナーシッ プ, 製薬企業におけるNTDs 治療薬の開発と提供 及び企業としての取り組み, 産官学による NTDs 創薬研究コンソーシアムの活動, 及び新たな官民 ファンドとしてグローバルヘルス技術振興基金を通 
した産官学パートナーシップについてを産官学から のシンポジストに紹介して頂いた．本シンポジウム を通じ, 日本薬学会会員及び創薬に関心のある皆様 にNTDs とその治療薬開発の必要性を知って頂く とともに，新規 NTDs 治療薬開発のために新たな 創薬の仕組みの創出が必要なことをご理解頂けると 思う。本シンポジウムの開催が NTDs 治療薬開発 への更なる参画の機会となり，わが国の産官学が有 する優れた科学技術力が NTDs 治療薬開発に活用 されることで日本発の新規治療薬を生みだし，感染 地域で苦しんでいる患者の治療のため大きな寄与が できるよう期待したい.

謝辞本シンポジウムの開催に当たり, 多大な ご支援・ご協力を頂いた DND $i$ Japan の松本眞理 氏及び森岡 翠氏に深く感謝します。

\section{REFERENCES}

1) Hotez P. J., "Forgotten People, Forgotten Diseases: The Neglected Tropical Diseases and Their Impact on Global Health and Development," University of Tokyo Press, Tokyo, 2015.

2) World Health Organization (WHO), Neglected tropical diseases: 〈http://www.who.int/ neglected_diseases/diseases/en/ $/$, cited 1 October, 2014.

3) World Health Organization (WHO), "Investing to Overcome the Global Impact of Neglected Tropical Diseases: Third WHO report on neglected tropical diseases," WHO, 2015.

4) Õmura S., Crump A., Nat. Rev. Microbiol., 2, 984-989 (2004).

5) Yoshida I., OPIR Views and Actions, No. 38, 1-6 (2013). 